\title{
PENDIDIKAN KARAKTER BERBASIS MADRASAH : STUDI KASUS DI MADRASAH DINIYAH NURUL MUSHOLLA SAMPANG
}

\author{
Muhammad Anshar, Abdul Muhid \\ UIN Sunan Ampel Surabaya \\ E-mail : masanshar12@gmail.com, abdulmuhid@uinsby.ac.id
}

\begin{abstract}
Abstrak
Madrasah Diniyah sebagai lembaga non-formal yang bergerak dalam menginternalisasikan nilai-nilai keagaman dan membentuk anak didik yang beraklakul karimah, tetap eksis di tengah modernitas. Tujuan penelitian ini ialah untuk mengetahui pendidikan karakter di Madrasah Diniyah Nurul Musholla dengan metode menghafal syair kitab Aqidatul awam dan efeknya terhadap karakter santri. Penelitin ini merupakan jenis penelitian kualitatif yang mengambil lokasi penelitian di Madrasah Diniyah Awwaliyah Nurul Musholla, Ketapang Barat, Ketapang, Sampang. Teknik pengumpulan data dalam penelitian ini menggunakan observasi, wawancara, dan dokumentasi. Penelitian ini menunjukkan bahwa Pembinaan karakter santri di Madrasah dengan penerapan metode hafalan aqidatul awam memberikan hasil yang efektif. Santri dapat menghafal dengan baik melalui pembiasan sebelum masuk kelas, proses hafalan dan setoran. Pemantapan akidah dan juga karakter dalam diri santri menjadi efektif. Santri dapat menjawab pertanyaan berkaitan dengan akidah seperti keesaan Tuhan, Nabi terakhir, ataupun keberadaan malaikat berdasarkan dalil teks hafalan aqidatul awam. Santri mampu mengaplikasikan nilai nilai pembelajaran dalam kehidupan sehari-hari.
\end{abstract}

Kata Kunci : Pendidikan Karakter, Madrasah Diniyah, Metode Hafalan

\begin{abstract}
Madrasah Diniyah as a non-formal institution engaged in the internalization of religious values and forming a student who is involved in a good morality, still exist amid modernity. The purpose of this research is to know the character education in Madrasah Diniyah Nurul Musholla with the method of memorizing the poem Aqidatul awam and its effect on the character of the students. This study is a type of qualitative research that took a research location at Madrasah Diniyah Awwaliyah Nurul Musholla, Ketapang Barat, Ketapang, Sampang. The data collection techniques in this study use observation, interviews, and documentation. The study showed that fostering the character of students in Madrasah by applying the aqidatul awam memorization method provides effective results. Student's can memorize well through refraction before entering the class, memorization and memorize deposit. Strengthening the creed and also the character in the students becomes effective. Santri can answer questions related to the creed such as the oneness of God, the last Prophet, or the existence of angels based on the text of the memorization in aqidatul awam. Santri can apply the values of learning in everyday life.
\end{abstract}

Keywords : Character Education, Madrasah Diniyah, Memorization Method 


\section{Pendahuluan}

Dalam Undang Undang Nomor 20 Tahun 2003 tentang sistem pendidikan Nasional berbunyi: "Pendidikan nasional berfungsi mengembangkan kemampuan dan membentuk watak serta peradaban bangsa yang bermartabat dalam rangka mencerdaskan kehidupan bangsa, bertujuan untuk berkembangya potensi peserta didik agar menjadi manusia yang beriman dan bertakwa kepada Tuhan Yang Maha Esa, berkahlak mulia, sehat, berilmu, cakap, kreatif, mandiri dan menjadi warga Negara yang demokratis serta bertanggung jawab". ${ }^{1}$

Dari uraian di atas dapat dijelaskan bahwa salah satu ciri manusia berkualitas adalah mereka yang tangguh iman dan takwanya, serta berakhlak mulia. Aidh Al Qarni menegaskan betapa pentingnya aqidah atau iman dalam kehidupan seseorang. Ia mengungkapkan bahwasanya tidak ada sesuatupun yang dapat membahagiakan jiwa, membersihkannya, menyucikannya, dan mengusir kegundahan darinya selain keimanan yang benar kepada Allah SWT. Sesunggunya orang-orang yang paling sengsara di antara mereka adalah yang miskin imannya, dan mengalami krisis keyakinan. Selamanya mereka akan berada dalam kesengsaraan, kepedihan, kemurkaan, dan kehinaan. Hidup akan terasa hambar tanpa iman. ${ }^{2}$

Hal senada diungkapkan Syaikh Fuhaim Musthafa, menurutnya seorang muslim membutuhkan akidah. Apabila ia mengetahui Allah SWT dan mempercayaiNya, maka dirinya akan merasakan ketenangan, dijauhi setan, dan terhindar dari permasalahan. Sehingga akan terlihat darinya nilai ajaran yang lurus dan benar. Apabila seorang manusia ditimpa suatu peristiwa yang tidak dikehendakinya, maka ia akan membutuhkan aqidah yang benar. Ajaran aqidah itu dapat memberikan kekuatan di dalam diri yang lemah, memberikan harapan di tengah keputus asaan, memberikan rasa takut dan menganugerahkan kesabaran di kala menghadapi kesusahan. Dengan beriman kepada Allah, seseorang akan selalu merasa gembira, optimis, dan memandang kehidupan dengan pandangan yang cerah. ${ }^{3}$

Madrasah Diniyah sebagai salah satu institusi pendidikan swasta yang berafiliasikan kepada pondok pesantren sangat erat kaitannya dengan metode salaf. Metode tersebut diataranya adalah sorogan, bandongan, halaqah dan hafalan (Mastuhu, 1994). ${ }^{4}$ Di antara metode pembelajaran yang umum daplikasikan ialah metode hafalan. Metode hafalan hingga saat ini masih banyak ditemukan di pendidikan tradisional seperti pesantren maupun madrasah di Indonesia. Metode hafalan digunakan untuk mempermudah santri dalam memahami materi pelajaran. Di antara materi pelajaran yang menggunakan hafalan ialah kitab yang berisi syairsyair seperti aqidatul awam, dimana bisa diiramakan dengan lagu yang menarik bagi santri. Metode ini diharapkan bisa membantu santri dalam memahami materi kitab mandzumat yang berisi 57 bait.

Masa kanak-kanak adalah masa yang paling tepat untuk mengisinya dengan hafalan seperti menghafal kitab aqidah ahlus sunnah wal jamaah, aqidatul awam.

\footnotetext{
1 Departemen Pendidikan Nasional, Undang-Undang Nomor 20 Tahun 2003, tentang Sistem Pendidikan Nasional, (Jakarta: Depdiknas, 2003).

2 Aidh Al-Qarni, La Tahzan Jangan Bersedih, terj. Samson Rahman, (Jakarta: Qisthi Press, 2005), 26.

${ }^{3}$ Asy-Syaikh Fuhaim Musthafa, Manhaj Pendidikan Anak Muslim, terj. Abdillah Obid dan Yessi HM Basyarudin (Jakarta: Penerbis Mustaqim, 2004), 73-74.

4 Mastuhu, Dinamika Sistem Pendidikan Pesantren (Jakarta: INIS, 1994), 61.
} 
Anak memiiliki kemampuan akal yang putih bersih yang tidak dipenuhi kesibukan dan pikiran seperti orang dewasa. Menurut John W. Santrock anak-anak yang masih belia mampu mengingat banyak informasi asalkan mendapat isyarat-isyarat dan bukti yang tepat. Dengan menggunakan strategi yang tepat maka akan membuat anak akan dapat mengingat dalam waktu yang lama. ${ }^{5}$

Megingat masa ini adalah masa emas bagi pertumbuhan, maka hendaknya masalah penanaman aqidah menjadi perhatian pokok bagi setiap orang tua yang peduli dengan nasib anaknya. Setiap anak dilahirlan di dunia dalam kondisi fitrah sebagaiamana firman Allah QS. Al'A'raf : 172. Adalah bagian dari karunia Allah pada hati manusia bahwa Dia melapangkan hati untuk menerima iman di awal pertumbuhanya tanpa perlu kepada argumentasi dan bukti nyata.

Bagi pendidik harus menerapkan penanaman akidah terhadap anak, meyakinkan dirinya untuk mengenal sejarah nabi dan rasul, mengenalkan mana yang baik dan mana yang buruk, dan menyuruh anak belajar Al-Qur'an agar terbiasa. Akidah memiliki peranan penting dalam membina akhlak setiap individu muslim sesuai dengan prinsip-prinsip agama yang pahala dan siksa disesuaikan dengannya, dan bukan hanya sekedar wejangan yang tidak menuntut tanggung jawab lain. Dengan demikian, musnahlah tuntunan-tuntunan akhlak dari kehidupan manusia, karena akhlak tanpa iman tidak akan pernah terwujud dalam kehidupan sehari-hari.

Madrasah Diniyah Awwaliyah yang berdiri sejak tahun 1999 didirikan oleh K. Abdul Karim yang berfahamkan ahlus sunnah wal jamaah memiliki kepedulian sangat tinggi terkait dengan penanaman aqidah untuk anak-anak sejak dini. Maka diterapkanlah hafalan nadhom aqidatul awam, demikian pula dengan materi-materi dasar yang berkaitan dengan keagamaan, seperti fiqh, tarikh, al-Qur'an dan tajwid, nahwu dan shorrof. Tentunya diharapkan dengan materi di atas anak-anak memiliki ketangguhan dalam aqidah secara umum. Maka pada penelitian ini, penulis ingin mengupas tentang metode hafalan kitab aqidatul awam dalam pemantapan pemahaman santri Madrasah Diniyah Awwaliyah Nurul Musholla Ketapang Barat, Ketapang, Sampang.

\section{Metode Penelitian}

Penelitian ini merupakan penelitian kualitatif yang berdasarkan kepada hasil verifikasi terkait efektivitas metode hafalan Aqidatul awam terhadap pemahaman akidah untuk santri Madrasah Diniyah Nurul Musholla. Metode kualitatif merupakan prosedur penelitian yang menghasilkan data deskriptif dari kata tertulis maupun moral dari orang-orang dan perilaku yang diamati. ${ }^{6}$

Adapun jenis penelitian ini ialah penelitian lapangan (field research), yakni peneitian dengan cara terjun langsung ke lokasi penelitian dan studi partisipatoris yaitu pengamatan langsung penelitian di lapangan, dengan lokasi penelitian di Madrasah Diniyah Nurul Musholla Ketapang Barat, Ketapang, Sampang. Penelitian ini mengupayakan memberikan gambaran detail latar belakang, sifat-sifat dan karakter yang khas dari kasus yang diamati kemudian ditarik suatu kesimpulan yang umum.

\footnotetext{
5 J. W Santrock, Perkembangan Anak, (Jakarta: Erlangga, 2007), 288.

${ }^{6}$ Lexi J. Moloeng, Metodologi Penelitian Kualitatif, (Bandung: Remaja Rosda Karya, 1989), 4.
} 
Teknik pengumpuan data penelitian ini melalui proses observasi, wawancara, dan dokumentasi. Metode observasi yaitu melakukan pengamatan terhadap objek penelitian secara langsung ataupun tidak langsung, ${ }^{7}$ observasi digunakan untuk mendapatkan data tentang keadaan geografis, sarana dan prasarana, kondisi sosial dan ekonomi, serta efektifitas penggunaan metode hafalan Aqidatul awam. Metode wawancara ialah mengajukan pertanyaan secara lisan kepada pencari informasi (interviewer) dan sumber informasi (interview). ${ }^{8}$ Wawancara ini ditujukan Ustad Abdul Karim, Kepala Madrasah Diniyah Nurul Musholla, Ustadah Rahmatum Mazidah, guru kelas, dan santri di MD Nurul Musholla, Rosi, Iffah, dan lainnya. Metode dokumentasi ialah metode mencari data mengenai hal-hal yang berupa catatan, transkrip, buku, majalah, surat kabar, notulen rapat, agenda dan sebagainya. ${ }^{9}$ Metode dokumentasi ini adalah untuk mencermati langkah-langkah guru dalam pembelajaran, prestasi santri dan fasilitas pendukung pembelajaran.

\section{Pembahasan \\ Pendidikan Karakter}

Secara bahasa, karakter berasal dari bahasa latin kharakter, kharassaein, dan kharax, dalam bahasa Yunani character dari kata charassein, yang berarti membuat tajam dan membuat tajam. ${ }^{10}$ Sementara menurut istilah terdapat beberapa pengertian tentang karakter. Menurut Simon Philips, karakter adalah kumpulan tata nilai yang menuju pada suatu system, yang melandasi pemikiran, sikap, dan perilaku yang ditampilkan. Sedangkan pandangan Doni Koesoema menyatakan bahwa karakter sama dengan kepribadian. Kepribadian dianggap sebagai ciri atau karakteristik atau gaya atau sifat khas dari diri seseorang yang bersumber dari bentukan-bentukan yang diterima dari lingkungan. ${ }^{11}$

Adapun Pengertian Karakter menurut Kementerian Pendidikan Nasional yaitu watak, tabiat, akhlak, atau kepribadian seseorang yang terbentuk dari hasil internalisasi berbagai kebajikan (virtues) yang diyakini dan digunakan sebagai landasan untuk cara pandang, berpikir, bersikap, dan bertindak. ${ }^{12}$

Pendidikan karakter memiliki makna lebih tinggi daripada pendidikan moral, karena pendidikan karakter tidak hanya berkaitan dengan masalah benar-salah, tetapi bagaimana menanamkan kebiasaan tentang hal-hal yang baik dalam kehidupan, sehingga peserta didik memiliki kesadaran, dan pemahaman yang tinggi, serta kepedulian dan komitmen untuk menerapkan kebajikan dalam kehidupan sehari-hari. ${ }^{13}$. Dengan demikian dapat dikatakan bahwa karakter merupakan sifat alami seseorang dalam merespon situasi secara bermoral, yang diwujudkan dalam

\footnotetext{
${ }^{7}$ Muhammad Ali, Penelitian Pendidikan Prosedur dan Strategi, (Bandung: PT Angkasa, 1987), 91.

${ }^{8}$ Aminul Hadin Harjono, Metodologi Penelitian Pendidikan, (Semarang: Thoha Putra, 1998), 135.

9 Suharsimi Arikunto, Prosedur Penelitian Suatu Pendekatan Praktik, (Jakarta: Rineka Cipta, 1993), 188.

${ }_{10}$ Abdul Mujib \& Dian Andayani, Pendidikan Karakter Perspektif Islam, (Bandung: PT. Remaja Rosda Karya, 2012), 11.

11 Doni Koesoema A, Pendidikan Karakter : Strategi mendidik Anak di Zaman Global, (Jakarta: Grasindo, 2010), 80.

12 Kemdiknas, Panduan Pendidikan Karakter di SMP, (Jakarta: Dirjen Pendas, 2011), 14.

13 E. Mulyasa, Manajemen Pendidikan Karakter, (Jakarta: Bumi Aksara, 2012), 13.
} 
tindakan nyata melalui perilaku baik, jujur, bertanggung jawab, hormat terhadap orang lain, dan nilai-nilai karakter mulia lainnya.

Dalam pendidikan karakter diperlukan juga aspek perasaan (emosi), menurut Lickona disebut "desiring the good" atau keinginan untuk melakukan kebajikan. Dalam hal ini ditegaskan bahwa pendidikan karakter yang baik harus melibatkan bukan saja aspek "knowing the good", akan tetapi juga "desiring the good " atau "loving the good" dan "acting the good", sehingga manusia tidak berperilaku seperti robot yang diindoktrinasi oleh paham tertentu Lickona menekankan pentingnya tiga komponen karakter yang baik, yaitu moral knowing atau pengetahuan tentang moral, moral feeling atau perasaan tentang moral, dan moral action atau tindakan moral. Ketiga komponen tersebut perlu diperhatikan dalam pendidikan karakter, agar peserta didik menyadari, memahami, merasakan dan dapat mempraktikannya dalam kehidupan sehari-hari nilai-nilai kebajikan itu secara utuh dan menyeluruh. ${ }^{14}$

Bangsa yang bukan hanya bangsa yang memiliki sumber daya alam (SDA) yang melimpah ruah melainkan didukung oleh sumber daya manusia (SDM) yang berkompetensi dalam mengelola dan mangatur SDA tersebut demit kesejahteraan dan kemakmuran rakyat. Sehingga dibutuhkan SDM yang mempunyai kecerdasan yang cukup, akhlak yang baik dan integritas yang tinggi pula. Pendidikan menempati posisi yang sangat vital dalam menciptakan SDM tersebut. ${ }^{15}$ Ahmadi mengatakan bahwa "maju tidaknya suatu bangsa bergantung kepada pendidika. Jika pendidikan suatu bangsa dapat menghasilkan manusia yang berkualitas lahir dan batin, otomatis bangsa tersebut akan maju, damai, dan terteram. Sebaliknya jika pendidikan suatu bangsa mengalami stagnasi maka bangsa tersebut akan terbelakang di segala bidang". 16

Dalam sistem pendidikan Indonesia, pendidikan karakter mempunyai fungsi dan tujuan masing-masing. Tujuan pendidikan karakter adalah untuk mengembangkan nilainilai yang membentuk karakter bangsa, yaitu Pancasila, meliputi: (1) mengembangkan potensi peserta didik agar menjadi manusia yang berhati baik, berperilaku baik, dan berpikiran baik; (2) membangun bangsa yang berkarakter Pancasila; dan (3) mengembangkan potensi agar mempunyai sifat percaya diri, bangga terhadap Negaranya dan bersikap baik kepada orang lain. Dilihat dari fungsinya, pendidikan karakter berfungsi untuk: (1) membangun kehidupan yang multikultural; (2) membangun kehidupan Bangsa yang cerdas, berbudaya luhur, dan berkontribusi dalam pengembangan kehidupan manusia; dan (3) membangun sikap yang cinta damai, kreatif, dan mandiri. ${ }^{17}$

Madrasah Diniyah sebagai salah satu lembaga non-formal cukup dikenal di masyarakat Indonesia. Kini keberadaan Madrasah Diniyah semakin diakui sebagai salah satu institusi pendidikan yang berperan dalam mencetak kader bangsa, yang religius dan berkaraktes sholih. Madrasah Diniyah yang lahir dari rahim pesantren merupakan lembaga pendidikan yang menginternalisasikan pemahaman, penghayatan, dan pengamalan ajaran Islam (tafaqquh fid din) dengan terus menerus

\footnotetext{
14 Thomas Lickona, Education for Character, terj. Juma Abdu Wamaungo, (Jakarta: Bumi Aksara, 2012), 51.

15 Abdulloh Hamid, Pendidikan Karakter Berbasis Pesantren, (Surabaya: IMTIYAS, 2007), 2.

${ }^{16}$ Abu Ahmadi, Psikologi Umum (Jakarta: Rineka Cipta, 2013), 1.

17 Kemdiknas, Pengembangan Pendidikan Budaya dan Karakter Bangsa, (Jakarta: Badan Penelitian dan Pengembangan Pusat Kurikulum Kemendiknas, 2010), 2.
} 
menekankan pentingnya moral agama Islam sebagai pedoman hidup bermasyarakat sehari hari.

Sehingga harapannya, pendidikan di sekolah yang menerapkan pendidikan karakter ialah dapat mencetak individu yang berkhlakul karimah dengan cara yang disesuaikah oleh madrasah. Melalui pembinaan yang menjadi rutinitas keseharian, lahirlah peserta didik dengan karakter Islami tanpa adanya paksaan. Jadi karakter adalah dapat merefleksikan nilai-nilai dalam kehidupan sehari-hari.

\section{Metode Hafalan}

Kata metode berasal dari bahasa Inggris Method yang memiliki arti cara. Metode merupakan cara tepat dan cepat dalam melakukan sesuatu. ${ }^{18}$ Zuhairi mengungkapkan bahwa kata metode berasal dari Yunani yaitu "metha" dan "hodos". Kata Metha bermakna melalui atau melewati, sedangkan hodos yaitu jalan atau cara yang harus dilalui atau dilewati untuk mencapai tujuan tertentu. ${ }^{19}$

Dalam bahasa Arab, menghafal berasal dari kata hafadza, bermakna menjaga, memelihata, dan melindungi. ${ }^{20}$ Sedang di dalam kamus Bahasa Indonesia, kata menghafal berasal dari kata hafal, berarti telah masuk dalam ingatan tentang pelajaran atau dapat mengucapkan di luar kepala tanpa melihat buku atau catatan lain. Dibubuhi awalan me- sehingga memiliki arti berusaha meresapkan ke dalam pikiran agar selalu ingat. ${ }^{21}$ Menghafal juga berarti aktifitas mengingat (memorable), yang membawa kepada psikologi kognitif. Proses memori melewati tiga proses yaitu perekaman, penyimpanan dan pemanggilan. ${ }^{22}$

Secara teoritis, bisa dibedakan ketiga aspek yang berfungsi di dalam ingatan, yaitu mencamkan, kesan-kesan, menyimpan kesan dan kesan dan memproduksi kesan-kesan. Berdasarkan hal ini, ingatan didefinisikan suatu kecakapan dalam menerima, menyimpan dan memproduksi kesan-kesan. ${ }^{23}$ Metode menghafal merupakan teknik yang digunakan pendidikan dengan menyerukan peserta didiknya untuk menghafalkan sejumlah kata-kata (mufradat) atau kalimat-kalimat maupun kaidah-kaidah. ${ }^{24}$

Terdapat 4 teknik metode menghafal, yaitu : 1. Teknik Memahami kata atau kalimat ; memahami materi yang akan dihafal, dibaca berkali-kali, berusaha menghafal dengan menutup buku, menyetorkan hafalan, 2. Teknik membaca berulang-ulang dan menghafalnya, 3. Mendengar sebelum menghafal; diperdengarkan lewat rekaman (recorder) secara berulang ulang dengan konsentrasi kemudian menghafalkannya, 4. Menulis sebelum menghafal. ${ }^{25}$

\section{Aqidatul awam}

Kitab Aqidatul awam (عقيدة العو ام) adalah kitab syair-syair tentang tauhid Ahlus Sunnah wal Jama'ah, karangan Syaikh as-Sayyid al-Marzuqiy. Nama lengkapya

\footnotetext{
18 Ahmad Tafsir, Metodologi Pengajaran Agama Islam, (Bandung: Remaja Rosda Karya, 1995), 9.

19 Zuhairi, Metodologi Pendidikan Agama Islam, (Solo: Ramadhani, 1993), 66.

${ }^{20}$ Mahmud Yunus, Kamus Arab-Indonesia. (Jakarta: PT Mahmud Yunus Wahzuhriyah, 1990), 105.

21 Desy Anwar, Kamus Lengkap Bahasa Indonesia, (Surabaya: Amelia, 2003), 318.

22 Jalaluddin Rahmat, Psikologi Komunikasi (Jakarta: Remaja Rosda Karya, 2005), 63.

23 Sumadi Suryabrata, Psikologi Pendidikan, (Jakarta: Rajawali Press, 1990), 44.

${ }^{24}$ Abdul Mujib, Ilmu Pendidikan Islam, (Jakarta: Kencana, 2006), 209.

${ }^{25}$ Abdul Aziz, Kiat Sukses Menjadi Hafidz Qur'an Da'iyah, (Semarang: Syamil Cipta Media, 2004), 52.
} 
adalah Ahmad bin Muhammad bin Sayyin Ramadan Al-Marzuqiy Al-Hasaniy wa AlHusainiy Al-Malikiy, lahir di Mesir pada tahun $1205 \mathrm{H}$. Berkat kepandaian dan kepiawannya, beliau diangkat menjadi mufti mazhab Maliki di Mekkah menggantikan Sayyid Muhammad (1261 H). Syaikh Marzuqiy dikenal sebagai seorang pujangga dan dijuluki dengan Abu Al-Fauzi

Syaikh Marzuqiy berguru kepada Syaikh al-Kabir Ibrahim Al-Ubaidiy, seorang ulama' di bidang qiro'ah asyrah. Sedangkan muridnya antara lain Syaikh Ahmad Damhan (1260 - 1345 H), Syaikh Ahmad Zaini Dahlan (1232 - 1304 H), Syaikh Thahir At-Takruniy dan lain sebagainya.

Kitab Aqidatul awam sebagai salah satu karangan Syaikh Marzuqiy, dilatarbelakangi oleh karena mimpi kepada Rasulullah. Dikisahkan bahwa pengarang bermimpi Rasulullah beserta para sahabatnya pada akhir malam Jum'at pertama di bulan Rajab. Dalam Syarah Jalaul Afham bi Syarhi Aqidah Al-Awam, KH, Ihya' Ulumuddin diceritakan bahwa Syaikh Marzuqiy bertemu Nabi Muhammad SAW sedang sahabat duduk mengelilingi. Kemudian beliau berkata : "Bacalah mandhumah (susunan bait syair) tauhid, barang siapa hafal mandhumah itu akan masuk surga dan akan memperoleh kebaikan yang sesuai dengan Al-Qur'an dan AsSunnah". Pengarang bertanya : "Apa mandhumah itu ya Rasulullah", para sahabat berkata : "dengarkan apa yang dikatakan oleh Rasulullah. Rasululah bersabda : "Ucapkanlah abdau bismillahi warrahmani (Saya memulai dengan nama Allah dan nama Dzat Yang Maha Pengasih). Pengarang membacakannya hingga bait terakhir "wa suhuful khalili wal kalimi, fiha kalamul hakamil 'alimi" (Kitab Nabi Khalil (Ibrahim) dan al-Kalim (Musa), dalam kitab suci mereka terdapat kalam Dzat Yang Maha Bijaksanana dan lagi Maha Mengetahui". Dan Rasulullah mendengarkannya. Ketika bangun, ia membaca apa yang ia lihat dalam mimpinya dan telah hafal dari awal sampai akhir bait. ${ }^{26}$

Pengarang bermimpi kembali bertemu Rasulullah untuk kedua kalinya pada waktu sahur. Nabi bersabda : "Bacalah apa yang engkau kumpulkan di dalam hatimu”. Kemudian pengarang membacanya dari awal sampai akhir bait, sedang ia duduk di hadapan Rasulullah dan para sahabatnya mengelilingi mengucapkan "Amin" setiap bait dari mandzumat yang dibacakan. Setelah pengarang selesai membacanya, Rasulullah SAW berkata : "Semoga Allah memberikan peetunjuk kepadamu terhadap apa yang Ia ridhoi dan menerima itu semua, memberkatumu dan orang-orang mukmin serta bermanfaat kepada semua hamba-Nya, Amin".

Kisah di atas menunjukkan kebersambungan sanad pengarang kitab Aqidatul awam sampai kepada Nabi Muhammad dan ditashhih langsung kepada Rasulullah. Pertemuan itu berlangsung di dalam mimpi. Memang seringkali ditemukan di dalalm muqaddimah kitab-kitab klasik tentang persaksian pengarang kepada Rasulullah dan memohon izin untuk mengarang suatu kitab. Artinya pengarang kitab bukan hanya menggunakan rasio dalam menggubah penanya, melainkan tidak melupakan unsur rasa, dalam contoh melalui mimpi buah dari laku spiritualnya.

Kitab Aqidatul awam ini oleh pengarangnya diberi nama "Tahshil Nail AlMaram Libayani Mandhumah Akidah Al-Awam". Terdapat beberapa kitab yang telah mensyarahnya, antara lain Nuruz\} Z\}alam 'ala Mandhumah Akidah Al-Awam, karya Syaikh Al-Imama An-Nawawiy Ats-Tsaniy al-Bantani Al-Jawiy As-Syafi'i, kitab

${ }^{26}$ Ihya' Ulumuddin, Jalaul Afham bi Syarhi Aqidah Al-Awam, (Malang: Nurul Haramain, 2004), 12-13. 
Tahshil Al-Maram li Darsil Aqidatil Awam, karya Syaikh Al-Qattha'aniy al-Aysawiy, kitab Jalaul Afham bi Syarhi Aqidah Al-Awam, karya KH. Ihya' Ulumuddin Pengasuh PP Nurul Haromain, Pujon, Malang.

\section{Hasil Penelitian}

\section{Teknik Metode Hafalan Aqidatul awam}

Kitab Aqidatul awam sebagai salah satu kitab pokok yang diajarkan di Madrasah Diniyah Awwaliyah Nurul Musholla merupakan kitab yang dasar dan cocok untuk kalangan usia madrasah diniyah awwaliyah, rasio peserta didiknya kisaran 6-13 tahun. Kitab aqidatul awam sendiri sangat mudah dipahami santri karena disampaikan dengan metode syair yang berjumlah 57. Kitab aqidatul awam ini bukan satu-satunya materi yang diajarkan di MD Nurul Musholla, melainkan masih ada kitab lain yang pembahasannya sama mengenai ilmu tauhid (aqidah), yaitu : kharidatul bahiyah, dan aqaid islamiyah

Demi memantapkan pembelajaran dan pemahaman santri, madrasah menggunakan beberapa metode, antara lain hafalan, imla', ceramah. Salah satu yang dibahas peneliti di sini ialah metode hafalan untuk memudahkan santri menguasai kitab aqidatul awam. Metode hafalan bukan hanya diterapkan dalam pembelajaran aqidatul awam, melainkan beberapa kitab juga, seperti tuhfatul athfal, kitab tashrif, kharidatul bahiyah, asmaul husna, do'a - do'a harian, bacaan sholat bagi anak kelas 1 dan 2.

Metode hafalan ini bertujuan untuk menanamkan nilai-nilai keislaman pada hati santri di tengah modernitas yang kian acuh akan warisan kitab salaf. Sebagaimana disampaikan oleh Ustad Abdul Karim, kepala Madrasah, bahwa anakanak diwajibkan menghafal seperti surat-surat di juz 30, maupun syair dalam kitab dengan landasan mempertahankan warisan ulama' salaf seperti hafalan aqidatul awam, almuhafadzatu ala qadimis shalih wal akhdu bil jadidil ashlah (memelihara tradisi lama yang baik dan mengambil tradisi baru yang lebih baik). ${ }^{27}$ Metode hafalan sangat penting diterapkan apalagi untuk anak usia dasar, tetapi tujuan utamanya dari hafalan syair seperti aqidatul awam bukan sekedar hafal, tetapi faham dengan akidah ahlus sunnah wal jama'ah. Dengan menghafal syair yang indah melalui lagu, para santri bisa menyerapnya dengan lebih mudah dan menyenangkan

Berdasarkan pengamatan peneliti, hafalan materi kitab aqidatul awam dikhususkan kepada anak kelas 3 dan 4. Untuk kelas 1 dan 2 diutamakan menghafalkan surat-surat pendek, do'a harian, bacaan sholat. Sedangkan untuk kelas 5 dan 6 menghafalkan kitab amstilatut tashrif, kharidatul bahiyah.

Peneliti menfokuskan studi kasus hafalan kitab aqidatul awam yang diajarkan pada anak kelas 3 dan 4 di Madrasah Diniyah Awwaliyah Nurul Musholla, serta pengaruhnya terhadap pemahaman aqidah anak. Program hafalan Aqidatul awam dalam memantapkan akidah santri dapat dilihat sebagai berikut

1. Menghafal sebelum pelajaran dimulai

Berdasarkan observasi di lapangan, santri kelas 3 dan 4 diharuskan untuk menghafalkan kitab aqidatul awal. Pada setiap hari sebelum pelajaran dimulai, santri membaca nadhom pada pelajaran akidah ataupun pelajaran lainnya. Para

27 Wawancara dengan Ustad Abdul Karim. 
santri membacanya ada yang bil ghaib (tanpa melihat teks) dan juga melihat teks bagi santri yang belum lancar hafalannya.

Kegiatan membaca nadhom aqidatul awam sebelum memulai pembelajaran secara bersama-sama ditujukan dalam rangka membiasakan dan memudahkan santri dalam memudahkan santri dalam menghafalkan nadhom. Bacaan nadhom dapat membuat santri gembira di saat membacakan bersamasama dengan menggunakan irama lagu yang beragam.

2. Mempelajari aqidatul awam di jam pelajaran

Bentuk dan variasi santri dalam menghafal nadhom aqidatul awam melalui program madrasah secara formil. Hal ini dapat dilihat pada jadwal pelajaran yang mengalokasikan 2 jam seminggu untuk belajar dan menghafal nadhom aqidatul awam.

Ustad/ah memberikan penjelasan syair sesuai dengan urutan pembahasan. Selain menghafal, santri perlu untuk mengetahui makna yang dihafalkannya. Penjelasan ini ditujukan untuk memupuk sejak dini santri memiliki dasar pengetahuan agama yang baik, terlebih berkaitan dengan akidah yang diharapkan dengan menghafal nadhom aqidatul awam setiap santri memiliki akidah yang benar dan mantap. Karena pola pikir anak-anak masih polos dan bersih inilah kemudian diinginkan santri mudah menerima materi aqidatul awam dan mudah menghafalkannya, juga menjadikan materi ini menancap dan kokoh di dalam diri santri, sehingga tatkala beranjak dewasa tidak mudah tergoyahkan akidahnya.

Pelajaran aqidatul awam di dalam kelas tidak hanya disampaikan terfokus kepada guru, namun dengan hubungan dua arah. Sebab hubungan dua arah dalam proses pembelajaan memungkinkan terjadinya arus balik dalam komunikasi baik yang datang dari santri kepada guru atau dari guru kepada santri. Hubungan semacam ini terjadi bilamana proses pembelajaran dilakukan misalnya dengan metode tanya jawab. Suasana kelas dengan pola hubungan dua arah jauh lebih hidup dan dinamis, ditandai dengan umpan balik bagi guru.

3. Setoran Hafalan

Ketika pembelajaran aqidatul awam berlangsung, guru menuliskan 2-3 bait beserta keterangannya. Santri menuliskannya dan mendapatkan penjelasan materi secara timbal balik antara guru dan santri. Setelah pemahaman telah disampaikan, bait-bait tersebut dibaca bersama-sama dengan dipimpin oleh ustad/ah yang membimbingnya, yang ditiru oleh peserta didik. Ketika sudah lancar dan benar bacaannya santri dipersilahkan untuk menghafalkannya, selanjutnya diberikan waktu 10 menit kesempatan bagi santri untuk menyetorkan hafalannya kepada guru.

Santri dapat menghafalkan di dalam kelas maupun di luar kelas disertai pengawasan ustad/ah. Bagi santri yang sudah hafal, disetorkan kepada guru sebagai persaratan sebelum istirahat ataupun pulang. Tidak semua santri bisa menghafalkan dengan baik sesuai kapasitas pikiran. Ada beberapa santri yang terbatas kemampuan hafalannya, maka dalam rangka menangani persoalan ini ustad/ah memberikan toleransi kepadanya dengan keharusan untuk membaca bait syair berkali-kali di hadapan ustad/ah.

\section{Pemahaman Santri Terhadap Materi Akidah}


Metode menghafal Aqidatul awam digunakan oleh MD Nurul Musholla dalam rangka menambah wawasan dan menguatkan akidah santri karena sudah dikemas dalam bait-bait syair yang sangat memudahkan santri untuk mempelajari dan menghafalkannya. Di usia kanak-kanak yang sangat mudah menghafal karena kebersihan mereka dari apapun, sangat tepat jika kemudian mereka disiapkan sejak dini untuk ditanamkan akidah yang yang benar

Dalam rangka inilah kemudian pengelola MD Nurul Musholla mengambil kebijakan untuk menjadikan mata pelajaran aqidatul awam dengan jadwal 2 jam dalam seminggu, untuk anak kelas 3 dan 4. Selain itu, pengelola MD Nurul Musholla berkeinginan agar setiap santri dengan menghafal nadhom aqidatul awam sejak awal sudah dicatat oleh Allah SWT sebagai penghuni surga-Nya sebagaimana yang telah dijanjikan sendiri oleh Nabi Muhammad SAW yang disampakan kepada Syaikh Ahmad Marzuqiy sebagai pengarang kitab aqidatul awam dan disaksikan oleh para sahabat.

Untuk mengkroscek pemahaman aqidah santri terkait pengaruh hafalan aqidatul awam. Maka diajukan beberapa pertanyaan kepada santri, antara lain bagaimana tanggapan santri jika ada yang mengaku sebagai tuhan, sebagai malaikat (padahal ia berupa manusia) ataupun sebagai nabi baru setelah nabi Muhammad.

Berdasarkan hasil wawancara kepada santri, peneliti menemukan beberapa jawaban seperti yang diutarakan ananda Rosi (kelas 4), "Tidak mungkin ada Tuhan selain Allah, karena Allah itu kan Esa, kalau ada manusia yang mengaku malaikat saya tidak percaya karna malaikat itu tentara Allah yang tidak makan dan minum, Nabi terakhir itu Nabi Muhammad, mustahil ada nabi baru sekarang". ${ }^{28}$


(berdiri degan sendiri tidak memerlukan bantuan yang lain) Yang Maha Kaya, Wahidun (Yang Maha Esa). Dalil tersebut menunjukkan keesaan Allah. Sedangkan dasar dari jawaban Malaikat tidaklah beranak seperti manusia, tidak makan dan tidaklah minum ialah:



"Ketahuilah, bahwa Malaikat itu tidak mempunyai ayah dan ibu, tidak makan, tidak minum dan tidak juga tidur".

Dan juga untuk mendasari bahwa tidak ada Nabi setelah Nabi Muhammad

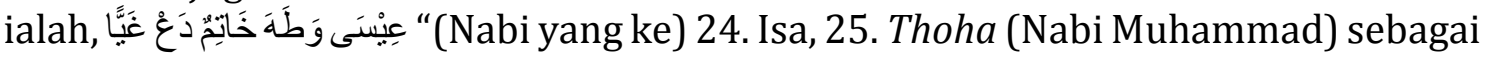
Nabi penutup dan tinggalkanlah kecenderungan kepada kesesatan"

Jawaban dari santri lainnya, Iffah (kelas 3) misalnya, "kata ustadah tidak ada Tuhan selain Allah, malaikat bukan manusia, dan Nabi Muhammad adalah Nabi terakhir tidak akan ada nabi setelahnya". ${ }^{29}$

Pemahaman santri tentang akidah dengan metode menghafal dan pemahaman, terlihat cukup berpengaruh di sanubarinya. Selain santri diajarkan akidah ahlus sunnah wal jama'ah, santri menghafalkan dasar landasan yang tertulis di dalam kitab Aqidatul awam. Santri merasa mudah menyerap materi-materi yang diajarkan dan merasa senang dengan lantunan irama lagu syiir Aqidatul awam, terlebih dilafalkan bersama-sama dengan santri lainnya.

\footnotetext{
28 Wawancara dengan saudara Rosi, santri kelas 4.

29 Wawancara dengan saudari Iffah, santri kelas 3.
} 
Hasil yang dicapai para santri dalam menghafalkan Aqidatul awam dapat dilihat dari ungkapan Ustadah Mazidah dan juga ungkapan santri yang mengalami proses sendiri. Bahwasanya santri bisa terkondisikan dengan baik berkat metode hafalan syair Aqidatul awam, para santri merasa senang gembira dan bisa menyerap pemahaman akidah dengan baik dan mudah. ${ }^{30}$

Hasil wawancara dan pengamatan peneliti di Madrasah Diniyah Nurul Musholla dapat memberikan gambaran bahwasanya standar kualitas pemahaman santri untuk mencapai tujuan, dalam hal ini pemahaman akidah dengan akidah Aqidatul awam sebagai berikut :

1. Santri bisa menghafalkan syair Aqidatul awam dan juga memahami isi kandungannya

2. Santri bisa mengaplikasikan dalam kehidupan sehari-hari terutama dalam hal kepercayaan.

Dari hasil penelitian menunjukkan bahwa metode menghafal nadhom Aqidatul awam di Madrasah Diniyah Awwaliyah Nurul Musholla sukses dilakukan oleh santri dan efektif dalam memantapkan akidah santri utamanya yang berkaitan dengan rukun iman, berhasil menghantarkan santri mencapai tujuan-tujuan instruksional yang telah ditetapkan dan memberikan pengalaman belajar yang atraktif, meningkatkan minat dan motivasi, melibatkan santri secara aktif sehingga menunjang pencapaian tujuan.

Hasil observasi juga menunjukkan bahwa semangat yang tinggi dari dewan asatidz membuat mereka lebih giat lagi untuk menjadikan anak-anak didiknya menjadikan mereka anak-anak yang berguna bagi agama, nusa dan bangsanya. Keberhasilan dalam penerapan metode menghafal Aqidatul awam untuk memantapkan aqidah santri juga karena pihak pengelola MD Nurul Musholla memberikan kebebasan kepada guru pengampu mata pelajaran aqidah di dalam pembelajarannya. Artinya guru dibebaskan menggunakan metode hafalan yang mana saja yang penting santri cepat dan tepat dalam menghafalkannya. Peneliti juga menilai bahwa metode menghafal itu mudah dan murah, tidak harus terikat ruang dan waktu, dan tidak membutuhkan biaya untuk mencapai keberhasilannya.

\section{Kesimpulan}

Pembinaan karakter santri di Madrasah Diniyah Nurul Musholla Ketapang, Sampang dengan penerapan metode hafalan aqidatul awam menunjukkan hasil yang efektif. Pola penerapan metode menghafal santri terhadap kitab aqidatul awam menunjukkan hasil yang jelas dengan santri mampu menghafal nadhom aqidatul awam dari awam sampai akhir dengan baik. Karena melalui proses pembiasan hafalan nadhom sebelum masuk kelas dan diperkuat lagi dengan proses hafalan dan setoran pada jam mata pelajaran tauhid. Selain itu, lagu yang dilantukan membuat santri lebih cepat dalam menghafalkan nadhom dan memberikan suasana yang lebih menyenangkan.

Penerapan metode menghafal ini dalam pembelajaran menjadi efektif memantapkan akidah dan juga karakter dalam diri santri. Dengan ditunjukkan berdasakan keberhasilan mengantarkan santri mencapai tujuan istruksional yang telah ditetapkan, memberikan pengalaman belajar yang atraktif, meningkatkan

30 Wawancara dengan Ustadzah Mazidah. 
minat dan motivasi belajar, dan melibatkan santri secara aktif sehingga menunjang tercapainya tujuan pembelajaran. Santri dapat menjawab pertanyaan berkaitan dengan akidah seperti keesaan Tuhan, pengakuan sebagai Nabi setelah Muhammad SAW, ataupun bentuk malaikat yang tidak menyerupai manusia, berdasarkan dalil teks hafalan aqidatu awam. Santri bisa mengaplikasikan dalam kehidupan seharihari, serta menunjukkan karakter religius dalam perilakunya.

\section{Daftar Pustaka}

Ahmadi, Abu, Psikologi Umum, (Jakarta: Rineka Cipta, 2003)

Al-Qarni, A, La Tahzan Jangan Bersedih, (Jakarta: Qisthi Press, 2005)

Ali, M, Penelitian Pendidikan Prosedur dan Strategi, (Bandung: PT Angkasa, 1987)

Anwar, D, Kamus Lengkap Bahasa Indonesia, (Surabaya: Amelia, 2003)

Arikunto, S, Prosedur Penelitian Suatu Pendekatan Praktik, (Jakarta: Rineka Cipta, 1993)

Depdiknas, Undang-Undang Nomor 20 Tahun 2003, (Jakarta: Depdiknas, 2003)

Gunawan, Heri, Pendidikan Karakter-Konsep dan Implementasi, (Bandung: Alfabeta, 2012)

Hamid, Abdulloh, Pendidikan Karakter Berbasis Pesantren, (Surabaya: IMTIYAS, 2007)

Harjono, A, H, Metodologi Penelitian Pendidikan, (Semarang: Thoha Putra, 1998)

Kemdiknas, Pengembangan Pendidikan Budaya dan Karakter Bangsa, (Jakarta: Badan Penelitian dan Pengembangan Pusat Kurikulum Kemendiknas, 2010)

Koesoema, Doni, Pendidikan Karakter : Strategi mendidik Anak di Zaman Global, (Jakarta: Grasindo, 2010)

Lexi J, Moloeng, Metodologi Penelitian Kualitatif, (Bandung: Remaja Rosda Karya, 1989)

Lickona, Thomas, Education for Character, Terj, Juma Abdu Wamaungo, (Jakarta: Bumi Aksara, 2012)

Mastuhu, Dinamika Sistem Pendidikan Pesantren, (Jakarta: INIS, 1994)

Mujib, A, Ilmu Pendidikan Islam, (Jakarta: Kencana, 2006)

Mulyasa, E, Manajemen Pendidikan Karakter, (Jakarta: Bumi Aksara, 2012)

Musthafa, S, F, Manhaj Pendidikan Anak Muslim, (Jakarta: Penerbit Mustaqim, 2004)

Rahmat, J, Psikologi Komunikasi, (Jakarta: Remaja Rosda Karya, 2005)

Rauf, Abdul Aziz Abdur. Kiat Sukses Menjadi Hafidz Qur'an Da'iyah, (Semarang: Syamil Cipta Media, 2004)

Santrock, J, W, Perkembangan Anak, (Jakarta: Erlangga, 2007)

Subagyo, J, Metodologi Penelitian Teori dan Praktek, (Jakarta: Rineka Cipta, 1991)

Suryabrata, S, Psikologi Pendidikan, (Jakarta: Rajawali Press, 1990)

Tafsir, A, Metodologi Pengajaran Agama Islam, (Bandung: Remaja Rosda Karya, 1995)

Ulumuddin, Ihya', Jalaul Afham bi Syarhi Aqidah Al-Awam, (Malang: Nurul Haramain, 2004)

Yunus, M, Kamus Arab-Indonesia, (Jakarta: PT Mahmud Yunus Wahzuhriyah, 1990)

Zuhairi, Metodologi Pendidikan Agama Islam, (Solo: Ramadhani, 1993) 